\title{
ARTICLE
}

\section{Greenhouse Gas Taxes on Meat Products: A Legal Perspective}

\author{
Cordelia Christiane Bähr*
}

\begin{abstract}
Meat production and the transport sector contribute almost equally to global warming. However, unlike the transport sector, in terms of climate change policies meat production is relatively unregulated. Many scientists have called for a meat tax as a means of reducing consumption but governments and politicians have not responded. Has the law been an obstacle to the acceptance of a meat tax? To address that question, this article analyzes three examples of European Union (EU) taxes that could be imposed on the consumption of domestic and imported meat, and examines them in relation to the international climate change regime, human rights law, and the legal regimes of the World Trade Organization and the EU. It shows that, if carefully designed, an EU meat tax is consistent with these bodies of law. To address adequately the industrial sectors that give rise to global warming, governments will need to overcome the taboo relating to the concept of a meat tax.
\end{abstract}

Keywords: Greenhouse gas tax, Meat consumption, Climate change law, World Trade Organization (WTO) law, European Union (EU) environmental law

\section{INTRODUCTION}

For climate change to be addressed effectively, urgent action is required from all industry sectors. ${ }^{1}$ Yet, in spite of the significant contribution of meat production to

* Faculty of Law, University of Zurich (Switzerland).

Email: cordeliabaehr@bluewin.ch.

The author would like to thank Veerle Heyvaert of the London School of Economics and Political Science for her support and encouragement in writing this article. All opinions and any errors are mine.

1 Cf. J. Gillis, 'UN Says Lag in Confronting Climate Woes Will Be Costly', The New York Times, 16 Jan. 2014, available at: http://www.nytimes.com/2014/01/17/science/earth/un-says-lag-in-confrontingclimate-woes-will-be-costly.html?_r $=0$. 
global greenhouse gas (GHG) emissions (ranging from $14.5 \%^{2}$ to $51 \%^{3}$ ), this sector is relatively unregulated.

From a purely scientific perspective, this regulatory shortfall is surprising. ${ }^{4}$ Firstly, sectors emitting at comparable levels, such as transport, are highly regulated. ${ }^{5}$ Secondly, it is expected that by 2050, GHG emissions from European Union (EU) agriculture will rise significantly and eventually represent a third of total EU emissions. ${ }^{6}$ Thirdly, a significant reduction in livestock would reduce GHG emissions relatively quickly compared with measures involving renewable energy and energy efficiency: ${ }^{7}$ methane, the major GHG associated with livestock, is 23 times more warming to the atmosphere than carbon dioxide $\left(\mathrm{CO}_{2}\right)$, and has a half-life of only about eight years in the atmosphere compared to at least a hundred years for $\mathrm{CO}_{2} \cdot{ }^{8}$ Fourthly, substituting for meat products is a comparatively easy and cost-effective way to reduce GHG emissions. ${ }^{9}$ Lastly, reducing meat production would have a number of other environmental benefits: raising livestock is the largest of all anthropogenic land uses, is responsible for over $8 \%$ of global human water use, and is a key factor in the loss of species. ${ }^{10}$

On the other hand, from an economic as well as a socio-cultural and political perspective, this regulatory shortfall is entirely understandable. Meat is a favourite food across the world. ${ }^{11}$ Moreover, taxes are politically unpopular with interest groups such as livestock lobbies, so policy makers tend to provide subsidies for 'clean' and 'green' technologies rather than putting a price on carbon emissions. ${ }^{12}$ The EU's

2 P.J. Gerber et al., Tackling Climate Change Through Livestock: A Global Assessment of Emissions and Mitigation Opportunities (Food and Agriculture Organisation of the United Nations (FAO), 2013), at p. 15 .

3 R. Goodland \& J. Anhang, 'Livestock and Climate Change' (2009) World Watch Magazine, pp. 10-9, at 14 .

4 Many scientists have called for the introduction of a meat tax to mitigate climate change: see, e.g., F. Hedenus, K. Mohlin \& S. Wirsenius, 'Greenhouse Gas-Weighted Consumption Taxes on Food as a Climate Policy Instrument', in C.D. Soares et al. (eds), Critical Issues in Environmental Taxation, International and Comparative Perspectives, Vol. VIII (Oxford University Press, 2010), pp. 376-92; W.J. Ripple et al., 'Ruminants, Climate Change and Climate Policy' (2014) 4(1) Nature Climate Change, pp. 2-5.

5 S. Wirsenius, F. Hedenus \& K. Mohlin, 'Greenhouse Gas Taxes on Animal Food Products: Rationale, Tax Scheme and Climate Mitigation Effects' (2011) 108(1-2) Climatic Change, pp. 159-84, at 160; cf. Regulation (EC) No. 443/2009 Setting Emission Performance Standards for New Passenger Cars as Part of the Community's Integrated Approach to Reduce $\mathrm{CO}_{2}$ Emissions from Light-Duty Vehicles (Passenger Car Regulation) [2009] OJ L140/1.

6 European Commission Communication on a Roadmap for Moving to a Competitive Low Carbon Economy in 2050, COM(2011)112 final, 8 Mar. 2011. See also B. Bajželi et al., 'Importance of FoodDemand Management for Climate Mitigation' (2014) 4(10) Nature Climate Change, pp. 924-9.

7 Goodland \& Anhang, n. 3 above, at p. 13.

8 H. Steinfeld, Livestock's Long Shadow: Environmental Issues and Options (FAO, 2006), at p. xxi.

9 Hedenus, Mohlin \& Wirsenius, n. 4 above, at p. 377.

10 Steinfeld, n. 8 above, at p. iii and pp. 270-3.

11 Oxfam International, Pasta, Pizza, or Paella? Global Food Survey Reveals World's Favorite Foods, 16 June 2011, available at: http://www.oxfam.org/en/grow/pasta-pizza-or-paella-global-food-surveyreveals-worlds-favorite-foods.

12 W. Nordhaus, A Question of Balance (Yale University Press, 2008), at p. 21; Steinfeld, n. 8 above, at p. 222: livestock lobbies are disproportionately strong, as can be seen by agricultural subsidies amounting to an average of $32 \%$ of total farm income in Organisation for Economic Co-operation and Development (OECD) countries. 
approach to climate change regulation generally favours win-win situations in which regulation creates economic opportunities. ${ }^{13}$ With regard to agricultural policies, the EU focuses on better fodder, improved livestock productivity, maximizing the benefits of extensive farming, ${ }^{14}$ and so forth - in short, measures in which innovation may yield economic benefits.

Politically, it has been easier to justify measures to reduce carbon emissions in the transport sector than in the agricultural sector. Besides promoting innovation, regulation in the transport sector can rely on the well known and far reaching problem of dependency on fossil fuels. Moreover, such regulation complements existing air quality measures to yield improved air quality in cities, as well as other health benefits. ${ }^{15}$

Reducing meat consumption would also come with many positive side effects, yet political discussion along these lines is only just beginning. Swedish authorities, in 2013, proposed a first-of-its-kind meat tax to reduce meat consumption on grounds of climate change, ${ }^{16}$ and the EU's 'roadmap to 2050' also mentions that it would be desirable to re-orient consumption towards less carbon intensive food. ${ }^{17}$

Against this background, this article will aim to address legal issues concerning three possible designs of a hypothetical EU tax on consumption of domestic and imported meat. Particular focus will be placed on international climate change law, World Trade Organization (WTO) law, human rights law and EU law.

Section 2 explains why I use the example of a hypothetical tax on consumption of domestic and imported meat. Section 3 analyzes whether such a meat tax would withstand international climate change and trade law. Section 4 examines whether a meat tax is in accordance with European environmental law and the general EU principle of proportionality, and Section 5 asks whether a meat tax is in accordance with the human right to eat. Conclusions are presented in Section 6.

\section{EU MEAT TAX ON CONSUMPTION}

Meat consumption in the context of climate change could be regulated in various ways. This article uses the example of a hypothetical EU tax on meat consumption for each category ${ }^{18}$ of domestic and imported meat. It could be levied on:

- average GHG emissions per unit for each category of meat for all producers on entire markets $^{19}$ (Type 1); or

13 V. Heyvaert, 'Governing Climate Change: Towards a New Paradigm for Risk Regulation' (2011) 74(6) The Modern Law Review, pp. 817-44, at 832.

14 Commission Communication on the Roadmap to 2050, n. 6 above.

15 Ibid.

16 R. Andersson et al., 'Hållbar köttkonsumtion Vad är det? Hur når vi dit? Rapport 2013:1', 22 Jan. 2013, available at: http://www.jordbruksverket.se/download/18.5df17f1c13c13e5bc4f800039403/ En + hållbar + köttkonsumtion.pdf; Spiegel Online, 'Klimaschutz: Schweden wollen europaweite Steuer auf Fleisch', 26 Jan. 2013, available at: http://www.spiegel.de/wirtschaft/service/schweden-will-euweite-steuer-auf-fleisch-a-879794.html.

17 Commission Communication on the Roadmap to 2050, n. 6 above.

18 E.g. ruminant meat, pork, poultry.

19 As proposed by Hedenus, Mohlin \& Wirsenius, n. 4 above. 
- uniformly based on average GHG emissions per unit for each category of meat (Type 2); or on

- actual GHG emissions per unit of meat of individual producers (Type 3).

This section will address the legal implications of such regulation.

The first reason for utilizing the example of a tax on meat consumption within the European Union is that meat consumption, which is typically connected with the average income in a country, ${ }^{20}$ is significantly higher in developed countries than it is in developing countries. Meat consumption per person in 2009 was 84.80 kilogrammes $(\mathrm{kg})$ in the EU, $17.6 \mathrm{~kg}$ across Africa and $4.4 \mathrm{~kg}$ in India. ${ }^{21}$ Secondly, the EU is clearly willing to take action to mitigate climate change, as evidenced by its offers to reduce GHG emissions by $40 \%$ by 2030 compared with 1990 levels, ${ }^{22}$ and by its prioritization of climate change among global environmental issues. ${ }^{23}$ Thirdly, there have already been calls within the EU to introduce a meat tax to mitigate climate change: the Swedish authorities have proposed a meat tax to reduce consumption ${ }^{24}$ and, in its 'roadmap' to 2050, the EU mentions that 're-orienting consumption towards less carbon intensive food would be desirable'. ${ }^{25}$

I propose a tax on meat despite the fact that, in principle, all categories of food could be subject to taxes on GHG emissions. ${ }^{26}$ One reason for this is that a tax on meat promises to be an efficient means of mitigating climate change. ${ }^{27}$ Meat alternatives cause only a fraction of the GHG emissions caused by meat. ${ }^{28}$ Similarly, vegetable foodstuffs are excluded because of their much lower GHG emissions per food unit and their lower elasticities. ${ }^{29}$ Furthermore, within the EU meat is responsible for 20 times more emissions per $\mathrm{kg}$ than milk. ${ }^{30}$ Lastly, it would also be

20 M. Gehlhar \& W. Coyle, 'Global Food Consumption and Impacts on Trade Patterns', in A. Regmi (ed.), Changing Structure of Global Food Consumption and Trade (Economic Research Service/USDA, 2001), at p. 6.

21 FAO Statistics Division (FAOSTAT), see http://faostat3.fao.org/home/index.html\#download.

22 European Council Conclusion, 24 Oct. 2014, EUCO 169/14, available at: http://www.consilium. europa.eu/uedocs/cms_data/docs/pressdata/en/ec/145397.pdf.

23 E. Morgera, 'European Environmental Law', in S. Alam et al. (eds), Routledge Handbook of International Environmental Law (Routledge, 2013), pp. 427-42, at 434.

24 Andersson et al., n. 16 above; Spiegel Online, n. 16 above.

25 Commission Communication on the Roadmap to 2050, n. 6 above.

26 Hedenus, Mohlin \& Wirsenius, n. 4 above, at p. 385.

27 Wirsenius, Hedenus \& Mohlin, n. 5 above, at p. 173; Steinfeld, n. 8 above, p. 269.

28 See C.G. Foster et al., 'Environmental Impacts of Food Production and Consumption: A Report to the Department for Environment Food and Rural Affairs', Defra and Manchester Business School, Dec. 2006, available at: http://www.ifr.ac.uk/waste/Reports/DEFRA-Environmental\%20Impacts\% 20of $\% 20$ Food $\% 20$ Production $\% 20 \% 20$ Consumption.pdf.

29 Hedenus, Mohlin \& Wirsenius, n. 4 above, at p. 385; $1 \mathrm{~kg}$ of bread wheat causes $0.8 \mathrm{~kg}$ of $\mathrm{CO}_{2}$-equivalent and $1 \mathrm{~kg}$ of potatoes $0.21 \mathrm{~kg}$ of $\mathrm{CO}_{2}$-equivalent, compared with $17.4 \mathrm{~kg}$ of $\mathrm{CO}_{2^{-}}$ equivalent from $1 \mathrm{~kg}$ of sheep and $12.98 \mathrm{~kg}$ of $\mathrm{CO}_{2}$-equivalent from $1 \mathrm{~kg}$ of beef: see Foster, n. 28 above.

30 Emissions per $\mathrm{kg}$ of meat from beef are $22 \mathrm{~kg}$ of $\mathrm{CO}_{2}$-equivalent $/ \mathrm{kg}$, while cow's milk has the lowest carbon footprint with $1.4 \mathrm{~kg}$ of $\mathrm{CO}_{2}$-equivalent $/ \mathrm{kg}$ : see A. Leip et al., 'Evaluation of the Livestock Sector's Contribution to the EU Greenhouse Gas Emissions (GGELS)', European Commission, Joint Research Centre, 30 Nov. 2010, available at: http://ec.europa.eu/agriculture/analysis/external/livestock-gas/exec_sum_en.pdf. 
an effective measure: tests by the Organisation for Economic Co-operation and Development (OECD) and the Food and Agriculture Organization of the United Nations (FAO) on the global agricultural sector ${ }^{31}$ have confirmed that consumption, and therefore GHG emissions, would fall with the introduction of a meat tax. It is estimated that a 7\% reduction in current GHG emissions in EU agriculture could be achieved if $€ 60$ per tonne of $\mathrm{CO}_{2}$-equivalent was added to the price. ${ }^{32}$

The first reason underlying my proposal for a tax is that a Pigovian tax is consistent with the regulatory emphasis on economic incentives in the Kyoto Protocol. $^{33}$ Economic incentives have a number of important economic and environmental advantages over command regulation. ${ }^{34}$ Firstly, command and control regulation is rarely politically feasible. Secondly, the existing market failure - excessive meat consumption is attributable to the fact that the meat industry and meat consumers do not internalize the consequences of their GHG emissions ${ }^{35}$ could be relatively easily resolved by governments through taxation. ${ }^{36}$ Thirdly, taxes provide signals to 'get the prices right'. 37

Getting the prices right would imply taxation to be levied on actual GHG emissions per $\mathrm{kg}$ of meat. This would mean designing the meat tax as an emissions tax as opposed to an output tax. For the latter, the content of GHG emissions is related to but not perfectly correlated with the emissions. ${ }^{38}$ However, a meat tax on output is preferable to a tax on actual emissions ${ }^{39}$ because of high monitoring costs, limited options for reducing emissions apart from reduced production (technical potential is limited), and high substitution possibilities. ${ }^{40}$ Thus, a better option is an output tax that is differentiated depending on the GHG emission levels per unit of meat for each category of meat, which is based on average emission levels for all meat producers within an entire market, rather than on specific emission levels of individual producers. ${ }^{41}$ In this spirit, Swedish authorities have suggested a tax of $€ 1.50$ per $\mathrm{kg}$ of beef. ${ }^{42}$

31 Email from H. Attariwala, Customer Contact Unit, Department for Environment, Food and Rural Affairs (Defra), 19 July 2013.

32 Wirsenius, Hedenus \& Mohlin, n. 5 above, at p. 173.

33 Kyoto Protocol to the United Nations Framework Convention on Climate Change, Kyoto (Japan), 10 Dec. 1997, in force 16 Feb. 2005, available at: http://unfccc.int/kyoto_protocol/items/2830.php.

34 See R.B. Stewart, 'Instrument Choice', in D. Bodansky, J. Brunnée \& E. Hey (eds), Oxford Handbook of International Environmental Law (Oxford University Press, 2007), pp. 150-81, at 155-6.

35 Steinfeld, n. 8 above, at p. 223; J.N. Galloway et al., 'International Trade in Meat: The Tip of the Pork Chop' (2007) 36(2) Royal Swedish Academy of Sciences, pp. 622-9; see R. Baldwin, M. Cave \& M. Lodge, Understanding Regulation; Theory, Strategy, and Practice (Oxford University Press, 2012), at p. 18 .

36 Cf. J. de Cendra de Larragán, Distributional Choices in EU Climate Change Law and Policy: Towards a Principled Approach? (Kluwer Law International, 2011), at p. 365.

37 K. Kosonen \& G. Nicodème, 'The Role of Fiscal Instruments in Environmental Policy', in Soares et al., n. 4 above, pp. 3-20, at 5 .

38 Hedenus, Mohlin \& Wirsenius, n. 4 above, at p. 378.

39 A. Schmutzler \& H. Goulder, 'The Choice Between Emission Taxes and Output Taxes under Imperfect Monitoring' (1997) 32(1) Journal of Environmental Economics \& Management, pp. 51-64.

40 Hedenus, Mohlin \& Wirsenius, n. 4 above, at pp. 378-9.

41 Ibid., at p. 380.

42 Spiegel Online, n. 16 above. 
That said, because the competitiveness of the EU agricultural sector is likely to be affected by the implementation of unilateral environmental taxes, ${ }^{43}$ and because of the possibility of carbon leakage, it is crucial to levy the meat tax on both domestic and imported meat (through border tax adjustment on imports ${ }^{44}$ ). Therefore, the tax should be imposed on consumption rather than production. ${ }^{45}$ Since meat is an everyday product with a relatively short shelf life, we may presume that the risk of the emergence of an unregulated market in untaxed meat within the regulated jurisdiction is small. However, even where taxes are levied on consumption, carbon leakage cannot be entirely avoided because decreased demand for meat within the EU would reduce world meat prices and result in increased meat consumption in non-EU countries. ${ }^{46}$ It is thought that if the EU reduces meat consumption by $20 \%$, international livestock prices would be reduced by between $3 \%$ and $11 \%$, which would cause meat consumption in the rest of the world to rise slightly. ${ }^{47}$

The following sections will analyze whether a meat tax on the consumption of domestic and exported meat (hereinafter 'the meat tax') is legally permissible, ${ }^{48}$ covering both the possibility of an output tax (levied on average GHG emissions per unit of meat category) and an emissions tax (levied on the actual GHG emissions).

\section{A MEAT TAX UNDER INTERNATIONAL LAW}

\subsection{Conflict with International Climate Change Regulation?}

Within the United Nations Framework Convention on Climate Change (UNFCCC) ${ }^{49}$ all parties have committed to implement national and regional programmes to mitigate climate change ${ }^{50}$ in all relevant sectors, including agriculture. ${ }^{51}$ Developed countries, such as those within the EU, are obliged to adopt policies to limit their GHG emissions to return to earlier levels of anthropogenic emissions. ${ }^{52}$ Some see this obligation as binding. ${ }^{53}$ Although the UNFCCC is silent on how this return to earlier

43 D. Kletzan-Slamanig et al., 'Ecological Tax Reform for Austria: An Evaluation of Economic and Emission Effects', in Soares et al., n. 4 above, pp. 57-75, at 60 .

44 A border tax adjustment consists of two situations: (i) the imposition of a tax on imported products, corresponding to a tax borne by similar domestic products, and/or (ii) the refund of domestic taxes when products are exported; cf. GATT Working Party, 'Border Tax Adjustments', Report of the Working Party, L/3464, Dec. 1970, available at: http://www.worldtradelaw.net/reports/gattpanels/ bordertax.pdf. This work concentrates on the former.

45 Wirsenius, Hedenus \& Mohlin, n. 5 above, at p. 6; Hedenus, Mohlin \& Wirsenius, n. 4 above, at p. 384. Responsibility (Martinus Nijhoff, 2005), at pp. 56-8 and 236; C. Voigt, 'State Responsibility for Climate Change Damages' (2008) 77 Nordic Journal of International Law, pp. 1-22, at 6. 
levels should be achieved, ${ }^{54}$ it does regard measures in the agricultural sector as relevant $^{55}$ and it explicitly allows for unilateral measures. ${ }^{56}$ Unilateral mitigation measures in the agricultural sector are thus supported by the UNFCCC as long as they are in accordance with the 'polluter pays' principle and the principle of common but differentiated responsibilities, and provided there is no 'arbitrary or unjustified discrimination or disguised restriction on international trade' (Article 3(5) UNFCCC).

Clearly, a meat tax would be an application of the 'polluter pays' principle, according to which those who cause damage to the environment should bear the cost of rectifying that damage, ${ }^{57}$ and taxes are an important means of promoting this principle. ${ }^{58}$ Although the 'polluter pays' principle is not explicitly mentioned in the UNFCCC, ${ }^{59}$ it is regarded by many as a customary rule of international law $^{60}$ and is therefore commonly associated with the UNFCCC.

\section{Principle of common but differentiated responsibilities}

On the other hand, a key principle in the climate change regime (albeit not legally enforceable $\left.{ }^{61}\right)$ is the principle of common but differentiated responsibilities. ${ }^{62}$ Article 3(1) UNFCCC states that ' $[\mathrm{t}]$ he Parties should protect the climate system ... in accordance with their common but differentiated responsibilities and respective capabilities. Accordingly, the developed country Parties should take the lead in combating climate change and the adverse effects thereof'. In implementing measures within the EU to combat climate change, this principle of common but differentiated responsibilities has to be taken 'into account'. ${ }^{63}$ The principle includes two elements:

54 D. Freestone, 'The International Climate Change Legal and Institutional Framework: An Overview', in D. Freestone \& C. Streck (eds), Legal Aspects of Carbon Trading: Kyoto, Copenhagen, and Beyond (Oxford University Press, 2009), pp. 3-34, at 6; Stewart, n. 34 above, at p. 171.

55 Art. 4(1)(c) UNFCCC.

56 M. Hertel, 'Climate-Change-Related Trade Measures and Article XX: Defining Discrimination in Light of the Principle of Common but Differentiated Responsibilities' (2011) 45(3) Journal of World Trade, pp. 653-78, at 662; Art. 3(5) UNFCCC.

57 S. Kravchenko et al., 'Principles of International Environmental Law', in Alam et al., n. 23 above, pp. 43-60, at 50 .

58 C. Coffrey and J. Newcompte, 'The Polluter Pays Principle and Fisheries: The Role of Taxes and Charges', Institute for Environmental Policy, at p. 1, available at: http://www.ieep.eu/assets/238/ thepolluterpaysprincipleandfisheries.pdf.

59 However, see Principle 16 of the Rio Declaration (Rio de Janeiro (Brazil), 3-14 June 1992, UN Doc. A/CONF.151/26/Rev.1 (Vol. I), 14 June 1992, available at: http://www.un.org/documents/ga/conf151/ aconf15126-1annex1.htm): 'National authorities should endeavour to promote the internalization of environmental costs and the use of economic instruments, taking into account the approach that the polluter should, in principle, bear the cost of pollution, with due regard to the public interest and without distorting international trade and investment'.

60 Kravchenko, n. 57 above, at p. 51.

61 Hertel, n. 56 above, at p. 665; P. Cullet, 'Differential Treatment in International Law: Towards a New Paradigm of Inter-state Relations’ (1999) 10(3) European Journal of International Law, pp. 549-82, at 575; L. Rajamani, Differential Treatment in International Environmental Law (Oxford University Press, 2006), at pp. 158-60; Y. Matsui, 'Some Aspects of the Principle of Common but Differentiated Responsibilities' (2002) 2(2) International Environmental Agreements: Politics, Law and Economics, pp. 151-71, at 167.

62 Kravchenko, n. 57 above, at p. 55.

63 Art. 4 (1) UNFCCC. 
on the one hand, the common responsibility of states with regard to the 'change in the Earth's climate and its adverse effects', which is a common concern of humankind; ${ }^{64}$ and, on the other hand, the contribution of each individual state to the creation of particular environmental problems and their individual abilities to prevent, reduce, and control the threat. In practice, the latter leads to environmental standards which impose differing obligations on states. ${ }^{65}$

All three types of a meat tax would affect the quantity of meat sales - and therefore the GHG emissions of meat production - not only within the EU (with regard to domestic products) but also from developing countries. It could be argued, therefore, that such a tax would place a disproportionate burden on developing states as they have lesser obligations to fulfil. For example, with regard to the (currently suspended ${ }^{66}$ ) EU aviation scheme, which included EU and non-EU airlines alike, the EU was accused of failing to reflect adequately the principle of common but differentiated responsibilities. ${ }^{67}$

However, unlike the aviation scheme, a meat tax would not impose any obligations on meat producers within developing countries. ${ }^{68}$ Moreover, it would not require developing countries to adopt GHG mitigation policies that are comparable in effect with those adopted by developed countries. ${ }^{69}$ Furthermore, the wider context should always be kept in mind: the ultimate objective of the UNFCCC is to identify the best way to avoid dangerous anthropogenic climate change. ${ }^{70}$ Moreover, the UNFCCC requires developed countries, on the basis of specific commitments, ${ }^{71}$ to provide financial assistance, to transfer technology, and to build capacity to support the implementation of adaptation action in developing countries. ${ }^{72}$ It does not prohibit unilateral measures that potentially affect developing countries.

Therefore, so as not to undermine developing countries' faith in the UNFCCC, ${ }^{73}$ differentiated responsibilities should be accomplished by other means. This could be achieved, for example, by transferring tax revenue to the developing countries,

64 Ibid., Preamble.

65 P. Sands, Principles of International Environmental Law (Cambridge University Press, 2012), pp. $233-4$.

66 Decision No. 377/2013/EU derogating temporarily from Directive 2003/87/EC Establishing a Scheme for Greenhouse Gas Emission Allowance Trading within the Community [2013] OJ L 113/1.

67 See O. Ruppel, 'Intersections of Law and Cooperative Global Climate Governance - Challenges in the Anthropocene', in O. Ruppel, C. Roschmann \& K. Ruppel-Schlichting (eds), Climate Change: International Law and Global Governance, Vol. II: Policy, Diplomacy and Governance in a Changing Environment (Nomos Verlagsgesellschaft, 2013), pp. 29-94, at 79.

68 Cf. D.H. Regan, 'How to Think About PPMs (and Climate Change)', in T. Cottier, O. Nartova \& S.Z. Bigdeli (eds), International Trade Regulation and the Mitigation of Climate Change (World Trade Forum, 2009), pp. 97-123, at 113 and 116.

69 Cf. Hertel, n. 56 above, at p. 654, who argues that measures that require a comparable effort are likely to be prohibited under the UNFCCC.

70 Ruppel, n. 67 above, at p. 79.

71 D. Bodansky, 'The United Nations Framework Convention on Climate Change: A Commentary' (1993) 18(451) Yale Journal of International Law, pp. 451-558, at 505.

72 Kravchenko, n. 57 above, at pp. 55-6; Decision 2/CP.15, Copenhagen Accord Art. 3, UN Doc. FCCC/ CP/2009/L.7, 18 Dec. 2009; Art. 4(3)-(5) UNFCCC.

73 Hertel, n. 56 above, at p. 678. 
enabling them to implement technical GHG emissions reduction measures. ${ }^{74}$ Moreover, removing subsidies to domestic producers could help to mitigate poverty and socio-economic inequality within many of these developing countries. ${ }^{75}$

\section{Unilateral trade measures under Article 3(5) UNFCCC}

What is the meaning of Article 3(5) UNFCCC in the context of the climate change regime? Does it prohibit a meat tax? The clause that 'unilateral trade measures should not constitute a means of arbitrary or unjustifiable discrimination or a disguised restriction on international trade ${ }^{76}$ is neutral in effect, as it does not define the types of trade measure that constitute 'arbitrary or unjustifiable' discrimination or are a 'disguised restriction on trade'. ${ }^{77}$ Hertel states that the concrete answer to this question was left for UNFCCC parties to determine at a later stage. ${ }^{78}$ Guidance could be sought from the WTO regime: the wording of Article 3(5) UNFCCC and the chapeau of Article XX of the General Agreement on Tariffs and Trade (GATT) ${ }^{79}$ are similar, and some argue that the two provisions should be interpreted similarly. ${ }^{80}$ However, the scope of Article 3(5) UNFCCC cannot be broader than Article XX GATT because the clause was included in the UNFCCC to ensure that mitigation measures taken by parties are consistent with the principles of the WTO regime. ${ }^{81}$ In addition, the UNFCCC aims primarily to mitigate climate change. Logically, it cannot then go further in protecting free trade than WTO laws, which aim primarily to protect free trade unless explicitly stated otherwise. Thus, if unilateral trade measures are compliant with GATT rules or justified under Article XX GATT, ${ }^{82}$ no separate issues arise under Article 3(5) UNFCCC. $^{83}$

74 Cf. Directive 2008/101/EC amending Directive 2003/87/EC so as to include Aviation Activities in the Scheme for Greenhouse Gas Emission Allowance Trading within the Community [2009] OJ L 8/3, Art. 3d(4), which states: 'It shall be for Member States to determine the use to be made of revenues (...). Those revenues should be used to tackle climate change in the EU and third countries, inter alia, to reduce greenhouse gas emissions, to adapt to the impacts of climate change in the EU and third countries, especially developing countries, (...)'

75 Ruppel, n. 67 above, at p. 77.

76 Art. 3(5) UNFCCC.

77 Bodansky, n. 71 above.

78 Hertel, n. 56 above, at p. 662.

79 Marrakesh (Morocco), 15 Apr. 1994, in force 1 Jan. 1995, available at: http://www.wto.org/english/ docs_e/legal_e/06-gatt_e.htm.

80 E. Denters, 'Free Riders, Claims and Countermeasures in Combating Climate Change', in N. Schrijver $\&$ F. Weiss (eds), International Law and Sustainable Development: Principles and Practice (Martinus Nijhoff, 2004) pp. 231-50, at 244.

81 J. Werksman, J.A. Bradbury \& L. Weischer, 'Trade Measures and Climate Change Policy: Searching for Common Ground on an Uneven Playing Field', World Resources Institute, WRI Working Paper, Dec. 2009, at pp. 5-6, available at: http://pdf.wri.org/working_papers/trade_measures_and_climate_change.pdf. See 'Justification under Article XX GATT', Section 3.2 below, for legal analysis of Art. XX GATT.

83 It remains possible, as some authors suggest, that the UNFCCC may play a role as an interpretative tool for the GATT rules. There are a multitude of views on this point. Ultimately, however, it is doubtful that unilateral trade measures on the grounds of carbon leakage could be sanctioned meaningfully through the climate change regime given the weak dispute settlement mechanisms of the UNFCCC: Hertel, n. 56 above, at pp. 662-3; Third World Network, 'Unilateral Trade Measures to Protect Climate Change Violate Climate Treaty - Say Developing Countries', TWN News Update, Aug. 2009, at p. 1, available at: http://www.twnside.org.sg. 


\section{A meat tax under the Kyoto Protocol}

The meat tax is in accordance with the Kyoto Protocol, which covers the gases emitted by livestock production ${ }^{84}$ and explicitly includes the agricultural sector. ${ }^{85}$ The measures named in the Protocol to reach its targets for Annex I countries are either national measures ${ }^{86}$ or are 'market mechanisms', which consist of emissions trading, Joint Implementation, and the Clean Development Mechanism. ${ }^{87}$ A regulation of the consumption of meat through a meat tax could qualify as a national measure. The EU might hesitate to implement measures that cause extraterritorial GHG reductions as they do not count towards its own emissions reduction target, ${ }^{88}$ but the Kyoto Protocol does not prohibit such a tax. The same applies to the Doha Amendment to the Protocol..$^{89}$

\subsection{A Barrier to International Free Trade?}

A meat tax must not only be in accordance with the international climate change regime, but also with WTO law. This regime is completely independent of the international climate change regime. ${ }^{90}$ However, following the Vienna Convention, ${ }^{91}$ the UNFCCC and the Kyoto Protocol could be applied in interpreting the rules of WTO law. ${ }^{92}$

If the EU were to act to mitigate global climate change with a meat tax, this would raise the following issues in WTO law. In the first place, when a tax is imposed the revenue gain to the importing country will generally be lower than would be the case without such a tax, and the EU is therefore implicitly expanding its mitigation efforts to countries outside the EU. Secondly, transaction costs of taxation arise. These costs are not limited to the government in its role as tax collector, but extend indirectly to international meat producers. ${ }^{93}$ Finally, food production in non-EU countries sometimes causes higher GHG emissions than equivalent production within the EU. This is especially true of cattle meat production in the tropics. ${ }^{94}$ Thus, if a meat tax results in a higher burden for such countries, de facto discrimination might arise.

84 Annex A Kyoto Protocol.

85 Ibid.

86 Ibid., Art. 6, para. 1 lit. (d).

87 Ibid., Arts 6, 12 and 17; Freestone, n. 54 above, pp. 12-7.

88 Cf. Art. 3(1) Kyoto Protocol.

89 Doha Amendment to the Kyoto Protocol to the UNFCCC, 8 Dec. 2012, Doha (Qatar), not yet in force, Art. 1A.

90 M. Friedrich, WTO und Klimaschutz, Konflikte und Synergien zwischen nationalen Klimaschutzmassnahmen und dem WTO-Recht (Peter Lang, 2012), at p. 29.

91 Vienna Convention on the Law of Treaties, Vienna (Austria), 23 May 1969, in force 27 Jan. 1980, available at: https://treaties.un.org/doc/Publication/UNTS/Volume\%201155/volume-1155-I-18232English.pdf.

92 Friedrich, n. 90 above, at p. 31.

93 J. Pavel \& L. Vitek, 'Environmental Tax Reform: Administrative and Compliance Costs of Energy Taxes in the Czech Republic', in Soares et al., n. 4 above, pp. 76-88, at 78-9.

94 Hedenus, Mohlin \& Wirsenius, n. 4 above, at p. 380; C. Cederberg, et al., Top-Down Life Cycle Accounting of Greenhouse Gas Emissions and Use of Land and Energy of Brazilian Beef Exported to Europe (Swedish Institute for Food and Biotechnology (SIK), 2009). Emissions intensities for the same livestock product vary largely between different regions of the world, whereby Europe and North America have lower emissions intensities than Africa, Asia, and Latin America: see Working Group III contribution 
As meat is an agricultural product, the question arises whether the applicable law within the WTO framework covers only the GATT or includes the Agreement on Agriculture (AoA). ${ }^{95}$ For a long time, agriculture had been accorded special treatment in the GATT. ${ }^{96}$ The Uruguay Round of the AoA marked a systemic shift ${ }^{97}$ and made important strides in creating open markets for agricultural products. ${ }^{98}$ It established binding commitments in three areas: reductions in farm export subsidies, ${ }^{99}$ an increase in import market access for developing countries, ${ }^{100}$ and cuts in domestic producer subsidies in developed countries. ${ }^{101}$ In areas not specifically covered by the AoA, the provisions of the GATT apply. ${ }^{102}$

A tax on meat consumption is neither a domestic producer subsidy nor an export subsidy. ${ }^{103}$ Furthermore, the AoA Market Access provision ${ }^{104}$ could even facilitate the imposition of a meat tax: a country that applies tariffs below the bound rates that resulted from the AoA may increase those without violating its commitments. ${ }^{105}$ However, even then the most-favoured treatment principle applies. ${ }^{106}$ Essentially, if a meat tax was found to be compliant with the GATT, no separate issues would arise under the AoA.

Unilateral trade measures such as an EU meat tax on domestic and imported meat are permissible under certain circumstances according to the rules of the GATT. Firstly, they must be eligible for border tax adjustment. Secondly, they may not discriminate between imports from another country and the country's own products ('national treatment': Article III GATT). Similarly, all other countries must be treated equally ('most-favoured nation': ${ }^{107}$ Article I GATT). ${ }^{108}$ Thirdly, if a violation of

to the Fifth Assessment Report of the Intergovernmental Panel on Climate Change (IPCC), 'Climate Change 2014: Mitigation of Climate Change', Ch. 11 'Agriculture, Forestry and Other Land Use (AFOLU)', final draft, 2014, at p. 35, available at: http://www.ipcc.ch/report/ar5/wg3.

95 Agreement on Agriculture (AoA), 15 Apr. 1994, Marrakesh Agreement Establishing the World Trade Organization, Annex 1A, available at: http://www.wto.org/english/docs_e/legal_e/14-ag_01_e.htm.

96 M.R. Grossman, 'The Uruguay Round Agreement on Agriculture and Domestic Support', in M.N. Cardwell, M.R. Grossman \& C.P. Rodgers (eds), Agriculture and International Trade Law, Policy and the WTO (CABI, 2003), pp. 27-48, at 27.

97 J.A. McMahon \& M.G. Desta, 'The Agreement on Agriculture: Setting the Scene', in J.A. McMahon \& M.G. Desta (eds), Research Handbook on the WTO Agriculture Agreement: New and Emerging Issues in International Agricultural Trade Law (Edward Elgar, 2012), pp. 1-44, at 1.

98 Grossman, n. 96 above, at p. 27.

99 Export Competition: Art. 8 AoA.

100 Market Access: Art. 4 AoA.

101 Domestic Support: Art. 6 AoA; S.P. Subedi, "Managing the "Second Agricultural Revolution" through International Law', in Schrijver \& Weiss, n. 80 above, pp. 161-84, at 167; B. Jack, Agriculture and EU Environmental Law (Ashgate, 2009), pp. 240-1.

102 Art. 21.1 AoA; European Communities - Regime for the Importation, Sale and Distribution of Bananas (EC - Bananas III), Appellate Body Report, WTO Doc. DS27/AB/R, 9 Sept. 1997, at pp. 69-70.

103 The same applies (even) to the elimination of indirect taxes on exports: see R.A. Westin, Environmental Tax Initiatives and Multilateral Trade Agreements: Dangerous Collisions (Kluwer Law International, 1997), at p. 152.

104 Art. 4 AoA.

105 D. Blandford, 'Climate Change Policies for Agriculture and WTO', in McMahon \& Desta (eds), n. 97 above, pp. 223-49, at 231.

106 Ibid.

107 Art. I GATT.

108 World Trade Organization, Understanding the WTO (World Trade Organization, 2011), at p. 66. 
GATT non-discrimination rules occurs, justification must be sought under the general exception clause of Article XX GATT.

\section{Eligibility of meat tax for border tax adjustment}

Only indirect taxes - taxes that are applied to products and not producers - may be adjusted at the border. ${ }^{109}$ Only these taxes incorporate the 'destination principle' (that products should be taxed only in the country of consumption) reflected by the provisions of the GATT in respect of border tax adjustments. ${ }^{110}$

When a tax is uniformly levied on demand of a certain product, it may qualify as an indirect tax adjustable at the border under Articles II:2(a) and III:2 GATT. ${ }^{111}$ Border tax adjustment is normal international practice in such cases. ${ }^{112}$ For example, many countries adjust domestic taxes on cigarettes, alcohol or fossil fuels. ${ }^{113}$

However, if a tax were to be levied on the GHG emissions associated with a certain product rather than on the product itself, the situation would be less clear. There is no case law so far that answers the question of whether such taxes could still qualify as indirect taxes (and therefore as taxes 'on the product'). In the US Superfund case, the WTO Dispute Settlement Panel left open the question of whether or not input, to which the tax is applied, must be physically present in the final product. ${ }^{114}$ Academic views with regard to carbon taxes differ. ${ }^{115}$ In Mexico - Taxes on Soft Drinks, the Panel found that Article III:2 GATT 'requires some connection, even if indirect, between the respective taxes (...), on the one hand, and the taxed product, on the other'. ${ }^{116}$ Most authors argue that carbon taxes (and the same must apply to GHG emission taxes) are indirect product taxes, provided there is a 'nexus' between tax and product. ${ }^{117}$ There is a close nexus between a meat tax and meat products for two reasons. Firstly, the tax is paid by consumers and not by producers, which is a characteristic of an indirect tax. Secondly, by internalizing the social cost of carbon, the intention is to limit the consumption of GHG-emission intensive products

109 A. Müller, T. Cottier \& R. Matteotti, 'Border Tax Adjustments, Can Energy and Carbon Taxes be Adjusted at the Border?', Ecoplan/World Trade Institute, Universität Bern/ Rechtswissenschaftliches Institut der Universität Zürich, 6 June 2013, at p. 84, available at: http://www.efv.admin.ch/e/ downloads/finanzpolitik_grundlagen/els/Ecoplan_2013_e.pdf; P. Demaret \& R. Stewardson, 'Border Tax Adjustments under GATT and EC Law and General Implications for Environmental Taxes' (1994) 28(4) Journal of World Trade, pp. 5-65, at 5; GATT Working Party, n. 44 above.

110 Westin, n. 103 above, at pp. 67 and 69.

111 Müller, Cottier \& Matteotti, at n. 109 above, at p. 84.

112 Ibid.

113 L. Tamiotti et al., Trade and Climate Change (World Trade Organization and United Nations Environment Programme, 2009), at p. 100, available at: http://www.wto.org/english/res_e/booksp_e/ trade_climate_change_e.pdf.

114 United States - Taxes on Petroleum and Certain Imported Substances (US - Superfund), Panel Report, WTO Doc. L/6175 - 34S/136, 17 June 1987.

115 Müller, Cottier \& Matteotti, n. 109 above, at p. 87.

116 Mexico - Tax Measures on Soft Drink and Other Beverages (Mexico - Taxes on Soft Drinks), Panel Report, WTO Doc. WT/DS308/R, 7 Oct. 2005, at p. 121.

117 C. Kaufmann, 'Carbon-related Border Tax Adjustment: Mitigating Climate Change or Restricting International Trade?’ (2011) 10(4) World Trade Review, pp. 497-525, at 500. 
like meat. ${ }^{118}$ Arguably, therefore, a WTO Dispute Settlement Panel would see all three types of the meat tax as eligible for border tax adjustment.

\section{National treatment}

To be WTO-compliant, a meat tax must be consistent with the national treatment obligation under Article III:2 GATT. ${ }^{119}$ To this end, it must first be examined whether the domestic and the imported products are 'like products'. ${ }^{120}$ Secondly, it must be determined whether domestic and imported like products are treated differently. ${ }^{121}$ Under a meat tax uniformly levied on average GHG emissions per unit for each category of domestic and imported meat, no distinction is drawn between imported and domestic products. For this type of tax, no issues arise under the national treatment obligation. Consequently, the following remarks relate only to scenarios in which a meat tax is levied on actual or on market-based average GHG emissions of a certain meat product, and the tax is higher for imported products (meat from the tropics, for example) than for domestic products.

To determine whether products are considered 'like products', four categories of 'characteristics' that products might share have been formulated: (i) their physical properties; (ii) consumers' tastes and habits; (iii) the products' end-uses in a certain market; and (iv) the international classification of products for tariff purposes. ${ }^{122}$ Within these parameters, are GHG-intensive meat (from the tropics, for example) and domestic low-GHG meat 'like' products? Can differences in the way in which two products are produced (so-called 'non product-related processes and production methods' (PPMs)) prevent them from being 'like products' even if they share all the relevant characteristics (apart from possibly consumer preferences), and even though GHG emissions are not traceable in the final meat product?

In EC - Asbestos, the Appellate Body found health concerns in the form of consumer tastes and habits to be a decisive factor in assessing the likeness between asbestos and other types of industry fibre. ${ }^{123}$ In Automobile Taxes, the Panel held that high-fuel efficient cars are not 'like' gas-guzzling cars. ${ }^{124}$ The Panel thus legitimized such regulatory distinctions. ${ }^{125}$ From these cases, it is arguable that if a product pollutes it is not 'like' the climate friendly product even if the products are physically alike.

118 J. Pauwelyn, 'U.S. Federal Climate Policy and Competitiveness Concerns: The Limits and Options of International Trade Law, Nicholas Institute for Environmental Policy Solutions, Duke University, Working Paper NI-WP-07-02, Apr. 2007, at p. 20, available at: http:/climateactionproject.com/docs/ internationaltradelaw.pdf.

119 Müller, Cottier \& Matteotti, n. 109 above, at p. 92.

120 Cf. M. Panizzon, L. Arnold \& T. Cottier, 'Handel und Umwelt in der WTO: Entwicklungen und Perspektiven' (2010) Umweltrecht in der Praxis, pp. 199-247, at 213.

121 Ibid., at p. 214.

122 GATT Working Party, n. 44 above; European Communities - Measures Affecting Asbestos and Asbestos-Containing Products (EC - Asbestos), Appellate Body Report, WTO Doc. WT/DS135/AB/R, 12 Mar. 2001, at p. 38.

123 EC - Asbestos, ibid., at p. 50; Panizzon, Arnold \& Cottier, n. 120 above, at pp. 216-7.

124 United States - Taxes on Automobiles (US - Automobile Taxes), unadopted Panel Report, WTO Doc. DS31/R, circulated 11 Oct. 1994, at paras 5.19-5.38.

125 C.R. Conrad, Processes and Production Methods (PPMs) in WTO Law, Interfacing Trade and Social Goals (Cambridge University Press, 2011), at p. 201. 
It is, however, questionable whether a claim that GHG-intensive meat is unlike low-GHG meat would stick. Consumer tastes and habits with regard to consumption of GHG-intensive meat are not clear, despite the fact that the environmental risk of meat production is confirmed by extensive scientific evidence. ${ }^{126}$ In a survey conducted by the leading German news magazine, Der Spiegel, asking readers' views on the regulation of meat consumption through a tax, $68.72 \%$ of 15,769 people favoured such a tax. ${ }^{127}$ This indicates a preference for low-GHG meat. On the other hand, a study by the European Commission revealed that only $12 \%$ of EU consumers look for climate friendly meat. ${ }^{128}$ Kysar and Vandenbergh state that this is because public awareness of the relationship between consumption and climate change is seriously lacking. ${ }^{129}$ Furthermore, a 2006 FAO Report suggests that society is inadequately informed and lacks sufficient understanding about the scope of the problem. ${ }^{130}$ So far, there is no case law on whether the protection of the environment is a relevant consideration in examining the likeness of products. Overall, it cannot therefore be excluded that GHGintensive meat (whether measured on market average or actual GHG emissions) and low-GHG meat would be found to be 'like' products.

If that is the case, GHG-intensive meat must not be taxed in excess of low-GHG meat (Article III:2 GATT), otherwise a violation of the national treatment principle will be presumed. ${ }^{131}$ 'Not in excess' does not even allow for a de minimis difference in the tax rate. ${ }^{132}$ However, justification of a meat tax levied on actual or market-based GHG emissions that apply different tax rates could still be sought under Article XX GATT.

\section{Most-favoured nation}

A meat tax must be consistent with the most-favoured nation treatment obligation under Article I GATT, which states that a WTO member must give imported like products from all WTO members the same benefits as are given to like products from any other country. ${ }^{133}$ With a meat tax uniformly levied on average GHG emissions per unit for each category of domestic and imported meat, no distinction is drawn based on the origin of imported products. Clearly, if a meat tax were to be levied on average emissions levels for all meat producers within certain markets, this would infringe the most-favoured nation principle and would need to be justified under Article XX GATT.

\footnotetext{
126 See 1. Introduction above, and cf. EC - Asbestos, n. 122 above, at p. 56.

127 Spiegel Online, n. 16 above; these figures were retrieved on 17 July 2013 at 17:40 hours.

128 European Commission, 'Functioning of the Meat Market for Consumers in the European Union', report based on the findings of the 'Study on the Functioning of the Meat Market for Consumers in the European Union', May 2013, at p. 5, available at: http://ec.europa.eu/consumers/archive/ consumer_research/market_studies/docs/mms_commission_report_en.pdf.

129 D.A. Kysar \& M.P. Vandenbergh, 'Climate Change and Consumption' (2008) 38 Environmental Law Reporter, pp. 10825-33, at 10829.

130 FAO, 'Livestock's Long Shadow' (2006), in Steinfeld, n. 8 above, at p. 282.

131 Japan - Taxes on Alcoholic Beverages (Japan - Alcoholic Beverages II), Appellate Body Report, WTO Doc. WT/DS8/AB/R, WT/DS10/AB/R, WT/DS11/AB/R, 4 Oct. 1996, at p. 18.

132 Ibid., at p. 23.

133 Müller, Cottier \& Matteotti, n. 109 above, at p. 90.
} 
A meat tax levied on actual GHG emissions of a certain meat product needs further analysis. Certainly, origin-based differentiation between like products violates the most-favoured nation principle. The WTO Dispute Settlement Panel has held that a derogation from this principle 'cannot be made conditional on any criteria that are not related to the imported product itself'. ${ }^{134}$ With respect to conditions completely unrelated to origin (such as PPMs) the Panel may find such conditions permissible for derogation under the most-favoured nation principle ${ }^{135}$ in the light of the Panel statement in Canada-Autos. ${ }^{136}$ Thus, GHG emission-related differentiation between meat products, regardless of the country of origination, would not violate the mostfavoured nation principle.

\section{Justification under Article XX GATT}

Meat taxes levied on actual GHG emissions of certain meat products, as well as meat taxes levied on average GHG emissions on certain markets, would potentially violate the GATT non-discrimination rules and would therefore need to be justified on the basis of Article XX GATT. There is scope for justification under Article XX(g), which allows Member States to adopt policy measures that relate to the conservation of exhaustible natural resources or, alternatively, under Article $\mathrm{XX}(\mathrm{b})$, which allows policy measures that are necessary to protect human, animal or plant life or health. If the measure falls within one of these exceptions, it must also fulfil the requirement of the introductory paragraph (the 'chapeau' of Article XX GATT). To be permitted under the chapeau, a measure must not cause unjustified or arbitrary discrimination between countries where the same conditions prevail or create a disguised restriction on international trade.

Although climate change mitigation measures have not yet been discussed by WTO bodies, ${ }^{137}$ it is likely that a meat tax to mitigate climate change could be justified under Article XX(b) and/or (g) GATT. For example, in US - Gasoline the Panel agreed that a policy to reduce air pollution resulting from the consumption of gasoline concerned the protection of human, animal, and plant life or health $(\mathrm{XX}(\mathrm{b}))^{138}$ and found clean air to be an exhaustible natural resource $(\mathrm{XX}(\mathrm{g})){ }^{139}$

It would be harder for a meat tax to pass Article $\mathrm{XX}(\mathrm{b})$ given the necessity test, which is far more stringent than the 'relating to' test of $\mathrm{XX}(\mathrm{g}) \cdot{ }^{140}$ In relation to Article $\mathrm{XX}(\mathrm{g})$, the Panel in US - Gasoline found clean air to be an exhaustible natural

134 Belgium - Family Allowances (Belgium - Family Allowances), GATT Panel Report, WTO Doc. BISD 1S/59, 7 Nov. 1952, at p. 9; confirmed in Indonesia - Certain Measures Affecting the Automobile Industry (Indonesia - Autos), GATT Panel Report, WTO Doc. WT/DS54/R, WT/DS55/R, WT/DS59/R, WT/DS64/R, 2 July 1998, at p. 356.

135 Müller, Cottier \& Matteotti, n. 109 above, at p. 92.

136 '[W] do not contest the validity of the proposition that Article I:1 does not prohibit the imposition of origin-neutral terms and conditions on importation that apply to importers': Canada - Certain Measures Affecting the Automotive Industry (Canada - Autos), GATT Panel Report, WTO Doc. WT/DS139/R, WT/DS142/R, 11 Feb. 2000, at p. 360.

137 Tamiotti et al., n. 113 above, at p. 107.

138 United States - Standards for Reformulated and Conventional Gasoline (US - Gasoline (Panel)), GATT Panel Report, WTO Doc. WT/DS2/R, 29 Jan. 1996, at pp. 38-9.

139 Ibid., at p. 44.

140 Müller, Cottier \& Matteotti, n. 109 above, at p. 101; Friedrich, n. 90 above, at p. 65. 
resource because it was natural and a resource (in that it had value). Although renewable, the Panel felt it could be depleted and was therefore exhaustible. ${ }^{141}$ Since climate is defined as the atmospheric conditions over longer periods of time (or average weather conditions), it is arguably analogous to air quality. ${ }^{142}$ Furthermore, mitigation measures do not aim to protect just the planet's atmosphere, but also to protect plant and animal species that may disappear as a result of global warming. ${ }^{143}$ Therefore, a stable climate could be considered an 'exhaustible natural resource'.

The fact that a meat tax on consumption of domestic and imported meat would also address GHG emissions emitted outside the EU does not necessarily work against such regulation. All that is required is a 'sufficient nexus' between the GHG emissions in the importing country and the climate change consequences of such GHG emissions for the EU. ${ }^{144}$ This nexus can be established relatively easily: in US Shrimp, the United States (US) was permitted to protect turtles in India. ${ }^{145}$ As the world's atmosphere is a global commons and GHG emissions of importing countries cross territorial borders, ${ }^{146}$ climate change caused by GHG emissions from meat production affects not only importing countries, but the EU as well.

The 'relating to' test of Article XX(g) GATT requires 'a close and genuine relationship of ends and means' and that the measure is not 'disproportionately wide in scope and reach in relation to the policy objective of protection and conservation'. ${ }^{147}$ An EU meat tax that puts GHG restrictions on the consumption of imported (and domestic) meat for the conservation of the planet's atmosphere and related climate seems to accurately reflect that relationship. ${ }^{148}$ Based on cases such as US - Shrimp and US - Gasoline, where the test was easily met, climate change legislation should normally pass the 'related to' test unless there are blatant inconsistencies or protectionist features in the legislation. ${ }^{149}$ It is by no means necessary to prove that no less restrictive measures exist or that mitigating climate change is the sole purpose of the measure. ${ }^{150}$

According to Article XX(g) GATT, climate legislation on imports must also be 'made effective in conjunction with restrictions on domestic production and consumption' ('even-handedness'). ${ }^{151}$ As long as the EU imposes broadly similar

141 US - Gasoline (Panel), n. 138 above, at p. 44.

142 Müller, Cottier \& Matteotti, n. 109 above, at p. 100; Pauwelyn, n. 118 above, at p. 35.

143 See Tamiotti et al., n. 113 above, at p. 108.

144 See Pauwelyn, n. 118 above, at p. 35; United States - Import Prohibition of Certain Shrimp and Shrimp Products (US - Shrimp), Appellate Body Report, WTO Doc. WT/DS58/AB/R, 12 Oct. 1998, at p. 51 .

145 Ibid., at p. 50-1.

146 See Pauwelyn, n. 118 above, at p. 35; Friedrich, n. 90 above, at p. 84.

147 US - Shrimp, n. 144 above, at p. 52.

148 See Müller, Cottier \& Matteotti, n. 109 above, at p. 100; Pauwelyn, n. 118 above, at p. 35.

149 Pauwelyn, n. 118 above, at p. 36.

150 Friedrich, n. 90 above, at p. 69; however, there are other views on that issue: see Kaufmann, n. 117 above, at p. 507.

151 United States - Standards for Reformulated and Conventional Gasoline (US - Gasoline (Appellate Body), GATT Appellate Body Report, WTO Doc. WT/DS2/AB/R, 29 Apr. 1996, at pp. 17-8. 
taxes on domestic meat, this condition will be met: identical treatment is not required; ${ }^{152}$ otherwise, it is difficult to see how a violation of the national treatment rule would have arisen in the first place. ${ }^{153}$ Thus, a meat tax on consumption of imported and domestic meat may differentiate insofar as the tax is levied on actual GHG emissions per unit of imported and domestic meat.

Finally, even if all of the conditions under the specific paragraph of Article $\mathrm{XX}(\mathrm{g})$ GATT were met, a meat tax that is to be found to violate GATT nondiscrimination rules would also have to fulfil the requirements of the chapeau of Article XX. ${ }^{154}$ The chapeau requires that 'measures are not applied in a manner which would constitute a means of arbitrary or unjustifiable discrimination between countries where the same conditions prevail, or a disguised restriction on international trade'. A meat tax should fulfil the following conditions in order to comply with the chapeau.

Firstly, such a tax must be sufficiently flexible to avoid 'arbitrary or unjustifiable discrimination' and must take into consideration 'prevailing different conditions in different foreign countries'. ${ }^{155}$ This might force the EU to differentiate between countries that already have their own climate policies in place and others that do not. ${ }^{156}$ Notably, different countries need not necessarily adopt exactly the same climate policies in order to achieve a reduction in GHG emissions. ${ }^{157}$

Furthermore, some argue that the principle of common but differentiated responsibilities must be taken into account in interpreting the chapeau provisions. Arguably, this might require developed country parties such as the EU to differentiate between developing and other countries. ${ }^{158}$ However, it does not follow that a meat tax would have to be substantially reduced or discarded. As discussed, there are less restrictive ways to cope with the principle. ${ }^{159}$ Moreover, it is debatable whether the (historical) factors that set countries apart and warrant differentiation in the climate change context should qualify as 'prevailing different conditions' under the GATT. ${ }^{160}$ This may be why the term 'prevailing conditions' does not feature in the otherwise similarly worded Article $3(5)$ UNFCCC. That said, whether a party is a member of the Kyoto Protocol is a relevant consideration when considering prevailing conditions. The fact that the EU ratified the Kyoto Protocol could compel the EU to exclude from its tax developing countries that have also ratified it, because developing countries have not $\left(\right.$ yet $^{161}$ )

\footnotetext{
152 Pauwelyn, n. 118 above, at p. 36; US - Gasoline (Appellate Body), ibid., at p. 21.

153 US - Gasoline (Appellate Body), ibid., at p. 21.

154 See Pauwelyn, n. 118 above, at p. 37.

155 Ibid., at p. 38; Tamiotti et al., n. 113 above, at p. 109; US - Shrimp, n. 144 above, at p. 63.

156 Cf. Pauwelyn, n. 118 above, at p. 39. In this regard, it is irrelevant whether a country has ratified the Kyoto Protocol: see Friedrich, n. 90 above, at p. 91.

157 Friedrich, ibid., at p. 90.

158 Cf. Art. 31(3)(c) VCLT, n. 91 above; Hertel, n. 56 above, at p. 654; Friedrich, n. 90 above, at p. 93.

159 See above, Section 3.1. Principle of common but differentiated responsibilities.

160 L. Rubini \& I. Jegou, 'Who'll Stop the Rain? Allocating Emissions Allowances for Free: Environmental Policy, Economics, and WTO Subsidy Law' (2012) 1(2) Transnational Environmental Law, pp. 325-54, at p. 349 .

161 A new agreement is to be adopted at the $21^{\text {st }}$ Conference of the Parties in 2015 in Paris (France), which would be binding on all parties, both developed and developing: see 'The 2015 Agreement -
} 
committed to emissions reduction. ${ }^{162}$ The EU already implements tariff preferences for goods coming from such countries if they have 'effectively implemented' the Kyoto Protocol. $^{163}$

Secondly, according to US - Shrimp, 'good faith efforts' would be needed from the EU to negotiate an international agreement with all countries affected before considering a unilateral approach. ${ }^{164}$ Thus, the EU may have to propose a meat tax within, for example, UNFCCC negotiations. However, if negotiations fail, the EU could impose a meat tax unilaterally: the conclusion of multilateral agreements is not a prerequisite for justification under Article XX. ${ }^{165}$

Lastly, the implementation of a meat tax must respect basic fairness and due process. ${ }^{166}$ This includes hearing the concerned states and producers with regard to implemented climate policies and production processes. ${ }^{167}$ Additionally, the meat tax must not constitute a 'disguised restriction on international trade', which means that the tax must not result in protectionism. ${ }^{168}$

The difficulty of meeting the stringent requirements of the chapeau could be avoided if a meat tax was found to be non-discriminatory and, therefore, in accordance with the GATT rules. In that situation, the EU would not have to seek justification. ${ }^{169}$ Consequently, it might be advisable to levy the meat tax uniformly on average emissions per unit of meat instead of levying it on actual GHG emissions or on average emissions in certain markets.

\section{A MEAT TAX UNDER EU LAW}

\subsection{Conflict with EU Environmental Regulation?}

In 2007, political agreement was reached on an EU-wide reduction in GHG emissions by $20 \%$ by $2020 .{ }^{170}$ The EU Emissions Trading System (ETS) contributes towards this goal but covers less than half of the GHG emissions. Additional measures are therefore needed to cover the remaining emissions in areas such as agriculture and

Priorities for 2014', submission by Greece and the European Commission on behalf of the European Union and its Member States, Athens (Greece), Feb. 2014, at p. 2, available at: http://unfccc.int/files/ bodies/application/pdf/el-02-28-eu_adp_ws1_submission.pdf.

162 J. Pauwelyn, 'How to Win a WTO Dispute based on Non-WTO Law: Questions of Jurisdiction and Merits' (2003) 37(6) Journal of World Trade, pp. 997-1030; Rubini \& Jegou, n. 160 above, at p. 350.

163 Regulation (EC) No. 980/2005 of 27 June 2005 Applying a Scheme of Generalised Tariff Preferences [2005] OJ L 169/1, Art. 9(1)(b) in conjunction with Annex III Pt B; Permitted by European Communities - Conditions for the Granting of Tariff Preferences to Developing Countries, Appellate Body Report, WTO Doc. WT/DS246/AB/R, 20 Apr. 2014.

164 US - Shrimp, n. 144 above, pp. 65, 68-70.

165 United States - Import Prohibition of Certain Shrimp and Shrimp Products: Recourse to Article 21.5 of the DSU by Malaysia (US - Shrimp Art. 21), Appellate Body Report, WTO Doc. WT/DS58/AB/ RW, 22 Oct. 2001, at p. 42.

166 US - Shrimp, n. 144 above, at p. 74.

167 Friedrich, n. 90 above, at p. 94.

168 Tamiotti et al., n. 113 above, at p. 110.

169 Pauwelyn, n. 118 above, at p. 40.

170 The European Council recently agreed to a 40\% reduction target by 2030 compared with 1990 levels: European Council Conclusion, n. 22 above. 
transport. The target for these sectors would be a $10 \%$ reduction in emissions from 2005 levels. ${ }^{171}$

The EU is competent to legislate in the areas of agriculture and the environment, ${ }^{172}$ provided the measures are proportionate ${ }^{173}$ to the objectives of the Treaties. ${ }^{174}$ Moreover, the sustainable development ${ }^{175}$ of Europe and of the world ${ }^{176}$ is one of the main goals of the EU. The objectives of EU environmental policy are, inter alia:

- to preserve, protect and improve the quality of the environment;

- to protect human health;

- to ensure the prudent and rational utilization of natural resources; and

- to promote measures at the international level to deal with regional or worldwide environmental problems and, in particular, to combat climate change. ${ }^{177}$

A tax on the consumption of domestic and imported meat, as a means of reducing European and worldwide GHG emissions and thereby mitigating climate change, would clearly fall within this objective, as there are no substantive limits to the exercise of EU environmental competence. ${ }^{178}$

Moreover, the EU legislator is obliged to apply the environmental principles of Article 191 TFEU and Article 11 TFEU to EU secondary legislation. ${ }^{179}$ Article 191 TFEU states that EU policy on the environment shall aim at a high level of protection, while being precautionary and preventative. It further states that environmental damage should be rectified at the source and that the polluter should pay. These environmental principles have enabling and directive functions: ${ }^{180}$ they enable policy makers to encroach on basic rights, ${ }^{181}$ and they direct policy makers to act comprehensively and deliver a high level of protection. ${ }^{182}$ The 'polluter pays' principle provides the basis for the use of fiscal instruments for environmental protection. ${ }^{183}$ As interpreted in the $\mathrm{EU}$, the principle posits that environmental

171 Commission Communication, '20 20 by 2020: Europe's Climate Change Opportunity', COM(2008) 30 final, 23 Jan. 2008.

172 Treaty on the Functioning of the EU (TFEU), 26 Oct. 2012, Art. 2(2) in conjunction with Art. 4(2)(d) and (e), available at: http://eur-lex.europa.eu/LexUriServ/LexUriServ.do?uri = OJ:C:2012:326:FULL: EN:PDF.

173 On the principle of proportionality, see below Section 4.2.

174 Treaty on European Union (TEU) 26 Oct. 2012, Art. 5(4), available at: http://eur-lex.europa.eu/ LexUriServ/LexUriServ.do?uri = OJ:C:2012:326:FULL:EN:PDF.

175 See Art. 3(3) TEU; Arts 11 and 208 TFEU.

176 Art. 3(5) TEU.

177 Art. 191(1) TFEU.

178 Morgera, n. 23 above, at p. 436. It is notable that with regard to provisions of a fiscal nature, the TFEU (Art. 192) requires unanimous decision making by the Council.

179 De Cendra de Larragán, n. 36 above, at p. 108.

180 G. Winter, 'Environmental Principles in Community Law', in J.H. Jans (ed.), The European Convention and the Future of European Environmental Law (Europa Law, 2003), pp. 3-25.

181 For example, the principles of precaution and prevention were considered by the ECJ in the BSE case to justify the legal measures which prohibited the export of British beef against the farmers' right to property: C-180/96, United Kingdom v. Commission [1998] ECR I-2265, at para. 99; see de Cendra de Larragán, n. 36 above, at p. 109.

182 Winter, n. 180 above. See also Art. 114(3) TFEU.

183 De Cendra de Larragán, n. 36 above, at p. 108. 
protection should not depend on state aid or policies that place a burden on society. It should not target persons for eliminating pollution to which they did not contribute. ${ }^{184}$ Thus, in the Standley case, the European Court of Justice (ECJ) stated that farmers are not obliged to bear all the costs associated with nitrate pollution, but only those caused by their own activities. ${ }^{185}$

In order to pursue a high level of protection, and relying on the 'polluter pays' principle, the European Commission could take regulatory action through a tax on meat consumption. Indeed, it could be argued that there is a duty to regulate. Moreover, the precautionary principle substantially lowers the threshold needed for governments to justify action when faced with risks of unknown probability. ${ }^{186}$ In any event, the threshold to justify governmental action towards climate change should be easily met since the risks of climate change are well documented. ${ }^{187}$

However, the Commission has opted for an alternative approach to environmental protection through the Common Agricultural Policy (CAP). ${ }^{188}$ One of the measures introduced to make farming 'greener' specifies that farmers obtain financial support only if they adopt sustainable practices to promote soil quality, biodiversity, crop diversification and healthy grassland. ${ }^{189}$ It is questionable whether this measure, based on incentives for technical improvements, will be effective in mitigating climate change ${ }^{190}$ compared with a meat tax. ${ }^{191}$ The 'polluter pays' principle is notably absent from this measure.

The approach is different from that applied towards the car industry. Although livestock emissions and emissions from transport produce approximately the same amount of GHG emissions, ${ }^{192}$ the car industry faces much stronger restrictions than does the meat industry. The car industry does not face a loss of financial aid if it fails to comply with environmental standards, but instead faces penalty payments ('excess emissions premiums' $)^{193}$ if it does not comply with the mandatory $\mathrm{CO}_{2}$ emission limits set in the Passenger Car Regulation. Furthermore, cars must be furnished with $\mathrm{CO}_{2}$ emissions data. ${ }^{194}$

184 J. Jans \& H. Vedder, European Environmental Law (Europa Law, 2008), at pp. 43-5.

185 C-293/9, R v. Secretary of State for the Environment and Ministry of Agriculture, Fisheries and Food, ex parte Standley and Metson [1999] ECR I-2603.

186 De Cendra de Larragán, n. 36 above, at p. 133.

187 Especially within the EU, climate change is no longer a risk with poor probability: see Heyvaert, n. 13 above, at p. 833.

188 Strengthened by agreed amendments in the form of 'delegated acts', whereas the first package was adopted in Mar. 2014: European Commission, 'The Common Agricultural Policy after 2013', 29 Aug. 2014, available at: http://ec.europa.eu/agriculture/cap-post-2013.

189 European Commission, 'Making Farming Fairer and Greener', 4 July 2013, available at: http://ec.europa.eu/news/agriculture/130704_en.htm.

190 Wirsenius et al. state that there is low technical potential for emissions reduction in the agricultural sector: Wirsenius, Hedenus \& Mohlin, n. 5 above, at p. 159.

191 This is estimated to provide a 7\% reduction in GHG emissions: see Wirsenius, Hedenus \& Mohlin, ibid., at p. 173.

192 See Section 1 above.

193 Passenger Car Regulation, n. 5 above.

194 Directive 1999/94/EC relating to the Availability of Consumer Information on Fuel Economy and $\mathrm{CO}_{2}$ Emissions in respect of the Marketing of New Passenger Cars [2000] OJ L 12/16. 
In 2005, the Commission presented a proposal for a Directive that would require Member States to restructure their passenger car taxation systems to promote sustainability by reforming the tax bases to include elements related to $\mathrm{CO}_{2}$ emissions of passenger cars. ${ }^{195}$ It said that fiscal measures would represent a critical instrument in achieving $\mathrm{CO}_{2}$ reduction targets. ${ }^{196}$ Because passenger cars are a major source of GHG emissions, the introduction of a $\mathrm{CO}_{2}$-sensitive element would be proportionate as it serves the need to achieve the global EC objective of reducing GHG emissions. It would also meet the Community's commitments under the Kyoto Protocol. ${ }^{197}$ The same arguments to promote sustainability could similarly be applied to a meat tax. Although the proposal found too much political resistance to move forward, ${ }^{198}$ the obstacles to its adoption were of a political rather than a legal nature. As climate change awareness has grown, the prospects of success for a similar measure may have changed in the intervening years. Consequently, the environmental legal framework of the EU does not go against regulating the consumption of meat through taxation.

\subsection{Violation of the General EU Principle of Proportionality?}

Policy makers are not absolutely free to make choices about the distribution of a policy's burdens and benefits; the principle of proportionality imposes limits on these choices. ${ }^{199}$ The ECJ has held that, generally, the lawfulness of a Directive depends on whether it is appropriate and necessary to achieve the objectives legitimately pursued by the law and on whether the disadvantages caused are not disproportionate to the aims pursued. ${ }^{200}$ According to Javier de Cendra de Larragán, choices in climate change policies must stand in rational proportion towards the ends, must fulfil the need to achieve a rational proportion in the burden sharing between parties while not impinging in a disproportionate manner upon individual parties, and the decision-making process should involve all affected parties. ${ }^{201}$ In general, legal principles do not require specific political outcomes or pre-determined distributions of burdens and benefits. However, distributional choices can be assessed against the principle of equality, which obliges policy makers to justify any departure from equality in their decision making. ${ }^{202}$

195 European Commission, Proposal for a Council Directive on Passenger Car related Taxes, $\operatorname{COM}(2005) 261$ final, 5 July 2005.

196 Commission Staff Working Document annexed to the Proposal for a Council Directive on Passenger Car related Taxes, SEC(2005)809, 5 July 2005, at p. 3.

197 Ibid., at p. 10; Commission Proposal, n. 195 above, at p. 2.

198 The proposal for green circulation taxes has not so far received the required unanimous support of the Member States, although many of them have unilaterally drawn on its ideas in formulating their car tax systems: European Commission, Communication on Strengthening the Single Market by Removing Cross-Border Tax Obstacles for Passenger Cars, COM(2012)756 final, 14 Dec. 2012, at p. 3; European Commission, 'Taxation: Clarifying EU Rules on Car Taxes', 14 Dec. 2012, available at: http://europa.eu/rapid/press-release_IP-12-1368_en.htm.

199 De Cendra de Larragán, n. 36 above, at p. 99.

200 See Case C-331/88, R v. Minister of Agriculture, Fisheries and Food, ex parte Fedesa [1990] ECR I-04023.

201 De Cendra de Larragán, n. 36 above, at p. 99.

202 Ibid., at p. 100. 
The principle of proportionality might prevent the regulation of meat consumption if a meat tax were to be considered unnecessary. There are three ways in which a regulation might be deemed unnecessary: by the existence of (i) other appropriate (technical) mitigating measures in the agricultural sector; (ii) appropriate regulatory measures (such as the ETS); or (iii) measures in other sectors that are judged to be sufficient to mitigate climate change.

The first possibility finds support in the 2006 FAO Report which suggests technical options for reducing GHG emissions from livestock. ${ }^{203}$ Technical options include sequestering carbon through improved pastures. For methane, the productivity and efficiency of livestock production can be improved through better nutrition and genetics and improved manure management. The best way to control $\mathrm{N}_{2} \mathrm{O}$ is to maximize the efficiency of human nitrogen use. ${ }^{204}$ The FAO states that, if widely applied, these technical solutions could have a high impact on reducing GHG emissions. ${ }^{205}$ In its latest report, it estimates that a $30 \%$ reduction in GHG emissions from agriculture would be possible if producers used the technologies and practices with the lowest emissions intensity. ${ }^{206}$ However, such options are expensive. $^{207}$

The EU plans to concentrate on economic incentives to encourage farmers to introduce technical measures that reduce GHG emissions per produced unit. ${ }^{208}$ However, it is not claimed that these economic incentives will suffice to mitigate climate change. The United Kingdom (UK) Department for Environment, Food \& Rural Affairs (Defra) states that there is, in the longer term, limited scope for further reductions in GHG emissions because of the difficulty of delivering further efficiency from complex biological systems. Addressing these challenges would require great effort and a willingness to consider novel approaches. ${ }^{209}$ Some argue that output taxes on emission-intensive agricultural goods would be more efficient than technical measures in dealing with agricultural GHG emissions. ${ }^{210}$

Thus, although technical mitigation measures exist, they are not a panacea for reducing GHG emissions in the agricultural sector to target levels. Hence, it is extremely unlikely that their existence would call into question the proportionality of a meat tax.

The second basis on which a meat tax might be deemed unnecessary is in the view that the Kyoto Protocol and the ETS (the 'jewel in the EU crown' of climate change

203 Steinfeld, n. 8 above, at pp. 114-23.

204 Ibid., at pp. 115-23.

205 Ibid., at pp. 221-2.

206 Gerber at al., n. 2 above, at p. xiii.

207 It is suggested that there is no cost-effective way to substantially mitigate methane emissions: A. Bibbee, Green Growth and Climate Change Policies in New Zealand, OECD Economics Department Working Paper No. 893 (OECD, 2011), at p. 17.

208 European Commission on Making Farming Fairer and Greener, n. 189 above; Commission Communication on the Roadmap to 2050, n. 6 above.

209 Defra, '2012 Review of Progress in Reducing Greenhouse Gas Emissions from English Agriculture', Nov. 2012, at p. 8, available at: https://www.gov.uk/government/uploads/system/uploads/attachment_ data/file/69612/greenhouse-gas-agriculture-report-20121122.pdf.

210 Wirsenius, Hedenus \& Mohlin, n. 5 above, at p. 1. 
instruments $^{211}$ ) already represent a sufficiently strong system for climate change mitigation, so that there is no need for such a tax. However, these institutions have been highly criticized: Prins and his co-authors claim that the Kyoto Protocol has actually slowed the reduction of GHGs because it has created incentives to transfer production to areas like China with looser emissions norms, so that emissions have increased overall. ${ }^{212}$ They contend that Kyoto threatens to invert the 'polluter pays' principle into 'pay the polluter'. ${ }^{213}$ During the economic crisis, the efficiency of the Kyoto Protocol suffered even more. Prins and his colleagues name, as an example, the exclusion of eastern European countries because of their coal dependency. ${ }^{214}$ According to Nordhaus, none of the policies that have been implemented to date are efficient. The current Kyoto Protocol is seriously flawed in its environmental rationale, is inefficiently designed, and is likely to be ineffective. ${ }^{215}$ Similarly, Baldwin claims that the ETS, in the long term, slows the development of new technologies that may revolutionize environmental performance. ${ }^{216}$ Thus, according to academic commentators, it is by no means certain that current ETSs are sufficient to mitigate climate change so as to render other measures unnecessary.

The efficiency of current ETSs does not render meat regulation unnecessary. Nevertheless, political decision makers seem to view a meat tax as an inappropriate means of reducing climate change, because of its perceived threat to the economy compared with an ETS, and because of their general reluctance to take measures which reduce consumption levels. Instead, political decision makers favour ETSs because they are attractive to different interests - they suit the economically powerful as well as weaker parties as they can sell allowances. ${ }^{217}$ The Australian Labour government introduced carbon taxes in 2012. Both candidates for Prime Minister in the 2013 elections - Abbott and the Labour party candidate, Rudd - promised to abolish these taxes because they were perceived to have slowed down economic growth. ${ }^{218}$ Rudd suggested an ETS instead. ${ }^{219}$ Furthermore, although such systems are inadequate if growing consumption leads to absolute increases in GHG emissions, the solution so far has generally been to try and improve relative efficiency, rather than reducing absolute consumption levels. ${ }^{220}$

211 Heyvaert, n. 13 above, at p. 827.

212 G. Prins et al., How to Get Climate Policy Back on Course (The Mackinder Programme, 2009), at pp. 3 and 8 .

213 Ibid.

214 Ibid., at p. 8.

215 Nordhaus, n. 12 above, at p. 18.

216 R. Baldwin, 'Regulation Lite: The Rise of Emissions Trading' (2008) 2(2) Regulation and Governance, pp. 193-215, at 212.

217 R. Baldwin, M. Cave \& M. Lodge, Understanding Regulation; Theory, Strategy, and Practice (Oxford University Press, 2012) at p. 222; and Baldwin, ibid.

218 The Abbott government repealed the tax in July 2014: Australian Government, Department of the Environment, 'Repealing the Carbon Tax', available at: http:/www.environment.gov.au/climatechange/repealing-carbon-tax.

219 'Australian PM Kevin Rudd Calls Election for 7 September', 4 Aug. 2013, BBC News Asia, available at: http://www.bbc.co.uk/news/world-asia-23565387.

220 De Cendra de Larragán, n. 36 above, at pp. 414-5. 
The third basis on which a meat tax might be regarded as disproportionate lies in the assumption that measures in sectors outside agriculture make regulation through a meat tax unnecessary. Globally, $\mathrm{CO}_{2}$ emissions account for around $75 \%$ of the total anthropogenic emissions. As the energy sector contribution to $\mathrm{CO}_{2}$ emissions is $75 \%$, the main focus has been on reducing emissions in that sector. ${ }^{221}$ According to the European Commission, this sector has a high reduction potential: $99 \%$ by 2050 compared with $49 \%$ for the agricultural sector. However, the latter percentage only takes into account technical measures, not consumption-related reductions. ${ }^{22}$ Even though the Commission stresses the increasing importance of the agricultural sector in terms of climate policy ${ }^{223}$ and views the re-orientation of consumption towards less carbon intensive food as 'desirable,' it has not yet suggested the regulation of meat consumption. It states that if the agricultural sector does not achieve the projected emissions reduction, other sectors would need to reduce even further, despite high costs. ${ }^{224}$

Hence, political decision makers decided to impose the main burden of mitigation on the energy sector as the largest and most evident contributor of $\mathrm{CO}_{2}$ emissions rather than on the agricultural sector in general and the meat industry in particular. They decided in terms of perceived effectiveness ${ }^{225}$ - the 'necessity-need"226 - while disregarding measures leading to a reduction in consumption.

Nordhaus criticizes the fact that some sectors are favoured over others, ${ }^{227}$ which may suggest that the current approach is disproportionate. With regard to the distribution of reductions across industrial sectors, Nordhaus argues that it is important that the costs of emissions reduction are equalized across all sectors and countries. He suggests the imposition of harmonized carbon prices that apply everywhere, either through a universal carbon tax or a cap-and-trade system in which all countries and sectors participate so that all emissions are subject to trade. ${ }^{228}$ Near-universal participation in such programmes to reduce GHGs is crucial to avoid incurring substantial additional costs. Costs of abatement were very low for the initial reductions of GHGs but they would rise sharply for higher reductions. $^{229}$ Hence, according to Nordhaus, the substantial exclusion rather than inclusion of the agricultural sector from mitigation measures could be qualified as disproportionate.

Finally, the proportionality requirement could prohibit a meat tax if it caused disadvantages to the consumer that were disproportionate to the aims

221 Steinfeld, n. 8 above, at pp. 114-15.

222 Commission Communication on the Roadmap to 2050, n. 6 above.

223 Ibid.

224 Ibid.

225 See Heyvaert, n. 13 above, at p. 834, who states that 'from a regulatory perspective, the burning question is not whether warming presents an unacceptable risk ... but whether the arsenal of regulatory instruments designed to control climate change can make a dent in the problem'.

226 Ibid., at p. 825.

227 Nordhaus, n. 12 above, at p. 18.

228 Ibid., at pp. 5 and 17.

229 Ibid., at p. 19. 
pursued. ${ }^{230}$ In order to determine the tax rate, policy makers have to perform a difficult balancing act: the rate must be high enough to be effective, but must not be excessive. However, all Pigovian taxes face calibration difficulties, as Arthur Pigou himself admitted. ${ }^{231}$ They should not of themselves deter such regulation, and do not in the case of other EU policies. ${ }^{232}$

\section{A HUMAN RIGHT TO EAT MEAT?}

Finally, the question must be addressed whether regulation of meat consumption through a meat tax would violate human rights (especially a 'right to food' and the right to private life).

Article 11 of the International Covenant on Economic, Social and Cultural Rights explicitly mentions a right to 'adequate' food. ${ }^{233}$ However, the right to adequate food is not to be interpreted expansively as, for example, mandating the availability of a minimum package of calories, proteins and other specific nutrients. ${ }^{234}$ Hence, an interpretation that there is a right to eat tax-free meat under Article 11 is far-fetched.

It could be argued that the consumption of meat is subsumed within the right to a private life. $^{235}$ However, it is important to differentiate between a prohibition on eating meat and a tax on meat which results in more expensive meat. Privacy is a qualified right ${ }^{236}$ and may be restricted, for example, for the protection of health or for the protection of the rights of others, which could include the 'right to a clean environment'. ${ }^{237}$ A further possible restriction on the right to privacy is the right to food itself. Livestock consume more from the total food supply than they provide: they consume 77 million tonnes of protein contained in feedstuff that could be consumed by humans, and provide only 58 million tonnes of protein in exchange. With regard to dietary energy, the relative loss is

230 See $R$ v. Minister of Agriculture, Fisheries and Food, ex parte Fedesa, n. 200 above.

231 A. Pigou, 'Some Aspects of the Welfare State' (1954) 2(7) Diogenes, pp. 1-11.

232 Cf. Directive 2011/64/EU on the Structure and Rates of Excise Duty Applied to Manufactured Tobacco [2011] OJ L 176/24.

233 International Covenant on Economic, Social and Cultural Rights, New York (US), 16 Dec. 1966, in force 3 Jan. 1976, available at: http://www.ohchr.org/EN/ProfessionalInterest/Pages/CESCR.aspx.

234 UN Committee on Economic, Social and Cultural Rights, 'General Comment No. 12: The Right to Adequate Food (Art. 11)', 12 May 1999, at p. 2, available at: http://www.refworld.org/docid/ 4538838c11.html.

235 E.g., Art. 8 of the European Convention on Human Rights (ECHR), Rome (Italy), 4 Nov. 1959, in force 3 Sept. 1953, available at: http://www.echr.coe.int/Documents/Convention_ENG.pdf; or Art. 17(1) of the International Covenant on Civil and Political Rights (ICCPR), New York (US), 19 Dec. 1976, in force 23 Mar. 1976, available at: http://www.ohchr.org/en/professionalinterest/pages/ ccpr.aspx.

236 See Art. 8(2) ECHR and Art. 17(1) ('arbitrary or unlawful') ICCPR.

237 Although such a right is not explicitly stated in international treaties or the ECHR, it is said that environmental rights should be deduced from other existing human rights: see M.R. Anderson, 'Human Rights Approaches to Environmental Protection', in A.E. Boyle \& M.R. Anderson (eds), Human Rights Approaches to Environmental Protection: An Overview (Clarendon Press, 1998), pp. 1-23, at 4. It is, under certain circumstances, in fact entailed, e.g., in Art. 8(1) ECHR: see European Court of Human Rights (ECtHR), Hatton and Others v. United Kingdom, Application No. 36022/97, 8 July 2003. 
even higher. ${ }^{238}$ Thus, the need to secure food supply would support a reduction in meat consumption, in favour of alternative, higher yield foods. This is particularly important because of the expected negative impact of climate change on food supply. $^{239}$

\section{CONCLUDING REMARKS}

It is clear that current efforts to stabilize GHG concentrations in the atmosphere at a level that would prevent dangerous anthropogenic interference with the climate system (Article 2 UNFCCC) are insufficient. Similarly, it seems clear that there are few climate change mitigation measures as simple, cost-effective, and with as many positive side effects as reducing meat consumption. In contrast to, for example, technical measures in the transport sector, this measure seems obvious. Yet, at a time when both vegetarianism and meat consumption are increasing, and food cultures are clashing, a meat tax is a highly contentious issue.

A state is not free in its regulatory choices regarding mitigating climate change. It is bound by legal restrictions as to the measures available and, at the same time, by its legal responsibility for environmental protection. This article concentrated on the former and discussed the legal implications of an EU tax on domestic and imported meat. It showed that the legal analysis depends on how the tax is to be levied, and that if carefully designed, a meat tax is proportionate and compatible with international and EU law.

This article has not discussed in any depth the question of whether the failure to regulate meat consumption would affect state responsibility for climate change damage. Nevertheless, this question should be kept in mind. The failure to implement a meat tax as a mitigation measure is not just a violation of the 'polluter pays' principle and the principle of equality. Conflict could occur with regard to the EU's human rights duty to protect its citizens against climate disasters, ${ }^{240}$ and its duty not to cause transboundary harm. ${ }^{241}$ Given the clear contribution of meat products to global warming and the equally clear foreseeability of the damaging consequences of climate change, the EU should seriously consider such a measure as a means of taking

238 Steinfeld, n. 8 above, at p. 270.

239 O. De Schutter, 'Climate Change and the Human Right to Adequate Food', contribution of the Special Rapporteur on the Right to Food to the meeting convened by the Friedrich-Ebert-Stiftung with the Committee on Economic, Social and Cultural Rights, Geneva (Switzerland), 13 May 2010, available at: http://www.srfood.org/images/stories/pdf/otherdocuments/20100513_climate-changeand-the-human-right-to-adequate-food_en.pdf.

240 Future climate change catastrophes will have implications with regard to the right to life and family life embedded in various human rights treaties, and the positive obligation of states to take appropriate steps: see J. Spier, 'Legal Strategies to Come to Grips with Climate Change', in O. Ruppel, C. Roschmann \& K. Ruppel-Schlichting (eds), Climate Change: International Law and Global Governance Vol. I: Legal Responses and Global Responsibility (Nomos Verlagsgesellschaft, 2013), pp. 121-52; ECtHR, Budayeva and Others v. Russia, Application Nos. 15339/02, 21166/02, 20058/ 02, 11673/02 and 15343/02, 29 Mar. 2008, in which Russia was held responsible under Art. 2 ECHR for its failure to implement land-planning and emergency relief policies in the light of foreseeable risk of a mudslide that would lead to loss of life.

241 On state responsibility for transboundary harm through climate change, see Verheyen, n. 53 above, and Voight, n. 53 above. 
reasonable care ${ }^{242}$ towards mitigating climate change. ${ }^{243}$ Finally, it is important to note that even if a meat tax does not materialize in the near future, many of the lessons emerging from this analysis are transferable to proposals regarding the taxation of other GHG-intensive consumption goods.

242 P. Barton, 'State Responsibility and Climate Change: Could Canada be Liable to Small Island States?' (2002) 11 Dalhousie Journal of Legal Studies, pp. 65-87, at 78.

243 Cf. Verheyen, n. 53 above, at p. 187 and Voigt, n. 53 above, at p. 18. 